\title{
Kemampuan Koneksi Matematika Siswa Dengan Pendekatan Kontekstual Di SMPN 1 Banuhampu
}

\author{
${ }^{1} \mathrm{M}$. Imamuddin, ${ }^{2}$ Isnaniah, ${ }^{3}$ Ade Putra, ${ }^{4}$ Rahmadila \\ Program Studi Pendidikan Matematika, Institut Agama Islam Negeri Bukittinggi \\ Email:m.imamuddin76@yahoo.co.id
}

\begin{abstract}
Article History:
Received: DD-MM-YYYY; Received in revised form: DD-MM-YYYY; Accepted: DD-MM-YYYY; Available online: DD-MM-YYYY
\end{abstract}

\begin{abstract}
This research is motivated by the students'poorly mathematical connection ability, more teacher-centered learning. The purpose of this study was to find out whether the mathematical connection ability of students who took part in the learning with the contextual approach was better than the students' mathematical connection ability with the conventional approach in class VII Of Junior High School 1 Banuhampu. The type of this research used is experimental. In the experimental class the teaching and learning process is carried out by applying the contextual learning approach while the control class uses conventional learning. Based on the results of data analysis obtained $t_{\text {count }}=2.45>t_{\text {table }}=$ 1.67 so that the results of the study show that the mathematical connection ability of students who follow learning with a contextual approach is better than the students' mathematical connection ability with conventional approaches in class VII Of Junior High School 1 Banuhampu
\end{abstract}

Keywords: Mathematical Connection; Contextual Approach.

\begin{abstract}
Abstrak
Penelitian ini dilatarbelakangi oleh rendahnya kemampuan koneksi matematika siswa, pembelajaran yang lebih terpusat kepada guru. Tujuan penelitian ini adalah untuk mengetahui kemampuan koneksi matematika siswa yang mengikuti pembelajaran dengan pendekatan konstektual lebih baik dari kemampuan koneksi matematika siswa dengan pendekatan konvensional di kelas VII SMP N 1 Banuhampu. Jenis penelitian yang digunakan adalah penelitian eksperimen. Pada kelas eksperimen proses belajar mengajar dilakukan dengan menerapkan pendekatan pembelajaran konstektual sedangkan kelas kontrol dengan menggunakan pembelajaran konvensional. Berdasarkan hasil analisis data diperoleh $\boldsymbol{t}_{\text {hitung }}=\mathbf{2 , 4 5}>\boldsymbol{t}_{\text {tabel }}=\mathbf{1 , 6 7}$ sehingga diperoleh hasil penelitian bahwa kemampuan koneksi matematika siswa yang mengikuti pembelajaran dengan pendekatan konstektual lebih baik daripada kemampuan koneksi matematika siswa dengan pendekatan konvensional di kelas VII SMPN 1 Banuhampu
\end{abstract}

Kata Kunci: Koneksi Matematika; Pendekatan Konstektual.

(CAl-Khwarizmi: Jurnal Pendidikan Matematika dan IImu Pengetahuan Alam. This is an open access article under the Creative Commons - Attribution-ShareAlike 4.0 International license (CC BY-SA 4.0) 


\section{Pendahuluan}

Matematika adalah suatu ilmu tentang logika mengenai bentuk, susunan, besaran dan konsep-konsep yang berhubungan satu sama lainnya dengan jumlah yang banyak ${ }^{1}$. Keterkaitan antara konsep-konsep atau koneksi antar konsep-konsep matematika sangat hirarki. Koneksi matematika dapat diartikan sebagai keterkaitan dua atau lebih konsep matematika, matematika dengan bidang ilmu lain ataupun bidang studi lain dalam kehidupan seharihari.

Menurut NCTM, ada dua tipe umum koneksi matematika yaitu: modelling connections dan mathematical connections. Modelling connections diartikan sebagai hubungan situasi masalah yang muncul di dunia nyata atau dalam disiplin ilmu lain dengan representasi matematikanya, sedangkan mathematical connections merupakan hubungan antara kedua representasi yang ekuivalen dan antara proses penyelesaian dari masing-masing representasi ${ }^{2}$.

Menurut National Council of Teacher of Mathematics (NCTM) tahun 2000, koneksi matematika merupakan bagian yang penting yang harus mendapatkan penekanan di setiap jenjang pendidikan. National Council of Teacher of Mathematics (NCTM) menyebutkan bahwa: "Thinking mathematically involves looking for connections, and making connection builds mathematical understanding. Without connections, student must learn and remember many isolated concept and skill, with connections, they can build new understanding on previous knowledge" 3 .

NCTM di atas menyatakan bahwa berpikir matematis melibatkan koneksi, dan koneksi membangun pemahaman matematis. Tanpa koneksi, siswa harus belajar dan ingat tentang banyak kemampuan dan konsep tertentu. Dengan koneksi, siswa dapat membangun pengetahuan yang baru dari pengetahuan yang sebelumnya.

Dalam NCTM dijelaskan bahwa dengan kemampuan koneksi matematika siswa diharapkan dapat:

a. Mengenali dan menggunakan hubungan antara ide-ide matematika

b. Memahami bagaimana ide-ide matematika saling berhubungan dan saling mendasari satu sama lain untuk menghasilkan satu kesatuan yang utuh,

1 Erman Suherman, Strategi Pembelajaran Matematika Kontemporer (Bandung: FMIPA UPI, n.d.), 18.

2 Research Advisory Committee of the National Council of Teachers of Mathematics, "NCTM Curriculum and Evaluation Standards for School Mathematics: Responses from the Research Community," Journal for Research in Mathematics Education 19, no. 4 (1988): 33844, https://doi.org/10.2307/749544.

${ }^{3}$ National Council of Teachers of Mathematics, Principles and Standards for School Mathematics (Reston, VA: National Council of Teachers of Mathematics, 2000), http://archive.org/details/principlesstanda00nati. 
c. Mengenali serta menerapkan matematika di luar konsteks matematika ${ }^{4}$

Kemampuan-kemampuan yang diharapkan oleh NCTM yang menekankan aspek koneksi matematika menurut standar kurikulum NCTM adalah:

a. Siswa dapat menggunakan koneksi antar topik matematika.

b. Siswa dapat menggunakan koneksi antara matematika dengan disiplin ilmu.

c. Siswa dapat mengenali representasi ekuivalen dari konsep yang sama

d. Siswa dapat menghubungkan prosedur antar representasi ekuivalen

e. Siswa dapat menggunakan ide-ide matematika untuk memperluas pemahaman tentang ide-ide matematika lainnya.

f. Siswa dapat menerapkan pemikiran dan pemodelan matematika untuk menyelesaikan masalah yang muncul pada disiplin ilmu lain.

g. Siswa dapat mengeksplorasi dan menjelaskan hasilnya dengan grafik, aljabar, model matematika verbal atau representasi.

Pembelajaran matematika akan menjadi lebih bermakna dengan kemampuan koneksi, karena siswa mampu menerapkan matematika di dalam dan di luar konteks matematika, siswa dapat memahami bagaimana ide-ide matematika saling berhubungan dan membentuk satu kesatuan yang utuh. Disamping siswa mampu memahami bagaimana ide-ide saling berhubungan siswa juga mampu mengenali serta menggunakan koneksi di antara gagasan matematika.

Dengan demikian peran guru sangat penting dalam memunculkan koneksi siswa, sehingga siswa tidak mempelajari matematika secara terpisahpisah. Konsep-konsep matematika yang dipelajari siswa tidak bisa bertahan lama dalam ingatannya, karena konsep-konsep tersebut jarang diterapkan dalam kehidupan sehari-hari dan rumus-rumus yang ada dianggap sebagai sesuatu yang harus dihafal. Akibatnya, kemampuan koneksi siswa belum maksimal dan semua materi yang diberikan diterima begitu saja tanpa ada tindak lanjut. Hal ini mengindikasi kurangnya kemampuan koneksi siswa dalam menghubungkan ide atau gagasan yang ada dalam matematika serta kurangnya kemampuan siswa dalam menghubungkan gagasan matematika dengan kehidupan sehari-hari. Salah satu pendekatan yang dapat meningkatkan kemampuan koneksi matematika siswa yaitu pendekatan konstektual.

Menurut Sagala, pendekatan konstektual adalah konsep belajar yang membantu guru mengaitkan antara materi yang diajarkannya dengan situasi dunia nyata siswa dan mendorong siswa membuat hubungan antara

${ }^{4}$ National Council of Teachers of Mathematics, 64. 
pengetahuan yang dimilikinya dengan penerapannya dalam kehidupan sehari-hari ${ }^{5}$.

Pembelajaran dengan pendekatan konstektual melibatkan tujuh komponen utama, yaitu:

a. Konstuktivisme (Constructvism)

Konstuktivisme merupakan landasan berpikir dalam konstektual, yaitu pengetahuan yang dibangun oleh manusia sedikit demi sedikit yang hasilnya diperluas melalui konstek yang terbatas. Dalam pembelajarannya siswa diharapkan mampu untuk membangun pengetahuan tersebut dan memberikan arti yang nyata melalui pengalaman belajar. Karena pengetahuan bukanlah seperangkat fakta, konsep atau kaidah yang siap untuk diingat dan dipraktikkan.

b. Menemukan (Inquiry)

Menemukan mempunyai seprangkat siklus yaitu: observasi, bertanya, mengajukan dugaan, mengumpulkan data, dan menyimpulkan. Pengetahuan dan keterampilan yang diperoleh siswa tidak dari hasil mengingat seperangkat fakta, tetapi hasil menemukan sendiri dari fakta yang dihadapinya. Langkah-langkah kegiatan inquiryyaitu:

1) Merumuskan masalah,

2) Mengamati atau melaksanakan observasi,

3) Menganalisis dan menyajikan hasil dalam tulisan, gambar, laporan, bagan, tabel, dan karya lain,

4) Mengomunikasikan atau menyajikan hasilnya pada pihak lain (pembaca, teman sekelas, guru, audiens yang lain).

Hasil menemukan sendiri akan lebih lama diingat selain itu dengan menemukan sendiri nilai kepuasannya lebih tinggi daripada hasil pemberian. Untuk menumbuhkan kebiasaan siswa secaramkreatif agar bisa menemukan pengalaman belajar sendiri, berimplikasi pada strategi yang dikembangkan oleh guru.

c. Bertanya (Questioning)

Penerapan unsur bertanya difasilitasi oleh guru, kondisi ini akan membuat suasana kelas menjadi hangat dan akan banyak ditemukan unsur-unsur terkait yang sebelumnya tidak terpikirkan baik oleh guru maupun siswa.

d. Masyarakat belajar (Learning community)

Masyarakat belajar dapat terjadi apabila terjadi komunikasi dua arah. Dalam masyarakat belajar, siswa saling belajar satu sama lain, siswa bertanya dan siswa lain menjawab, mereka saling bertukar pikiran, bertukar pendapat dan bertukar pengalaman. Tugas guru dalam pembelajaran ini bukan hanya menjelaskan dan menjawab pertanyaan

${ }^{5}$ Syaiful Sagala, Konsep Dan Makna Pembelajaran (Bandung: CV. Alfabeta, 2009), 87. 
siswa namun mengelola kelas agar terjadinya saling bertanya, saling menjawab, saling bertukar pikiran bertukar gagasan dan saling berbagi pengelaman antara sesama siswa.

e. Pemodelan (Modelling)

Pemodelan yang dimaksud bukan hanya guru namun bisa berupa penggunaan alar peraga, pemberian contoh, atau cara membuat skema konsep. Pemodelan membantu mengatasi keterbatasan guru dan juga dapat mengembangkan pembelajaran agar bisa memenuhi harapan siswa

f. Umpan balik (Reflection)

Umpan balik atau refleksi merupakan cara berpikir tentang apa yang baru dipelajari atau mengulang kembali tentang apa-apa yang sudah dilakukan dan diperoleh di masa lalu. Refleksi yang dimaksud antara lain;

1) Siswa dapat menuliskan kembali hasil pemikiran yang diperolehnya berdasarkan idenya sendiri,

2) Siswa dapat menyatakan dengan jelas tentang alasan dan kesimpulan dari permasalahan yang telah diberikan guru.

g. Penilaian yang sebenarnya (Authentic assesment)

Penilaian merupakan proses pengumpulan berbagai data yang dapat memberikan gambaran tentang perkembangan belajar siswa ${ }^{6}$.

Beberapa peneliti yang telah melakukan penelitian terkait koneksi matematis antara lain: Mujiyen Sapti dengan judul Kemampuan Koneksi Matematis (Tinjauan Terhadap Pendekatan Pembelajaran Savi). Berdasarkan hasil penelitian yang dilakukan oleh Mujiyen Sapti, pendekatan SAVI memiliki kesesuaian karakter dengan pembelajaran yang ingin mengangkat kemampuan koneksi matematis siswa. dengan pendekatan SAVI, kegiatan belajar dapat lebih optimal karena menggunakan segenap indera siswa. Dengan memanfaatkan segenap indera siswa, siswa akan makin terasah kemampuannya sehinnga mampu melihat hubungan antara topik lain, materi pelajaran matematika dengan pelajaran lain, serta matematika dengan kehidupan sehari-hari ${ }^{7}$. Rima Nur'Afifah dengan judul penelitian "Kemampuan Koneksi Matematis Pada Bangun Ruang Sisi Lengkung" hasil penelitiannya menyimpulkan bahwa faktor-faktor yang mempengaruhi kemampuan koneksi matematis adalah siswa kurang memahami materi prasyarat, siswa belum memahami apa kaitan matematika dengan mata pelajaran lain (fisika), siswa mengalami kesulitan menghubungkan materi yang dipelajari dengan materi yang ada pada pelajaran fisika, dalam pengerjaan yang dilakukan siswa masih kurang sistematis. Untuk itu perlu

6 Masnur Muchlish, KTSP Pembelajaran Berbasis Kompetensi Dan Konstektual (Malang: Bumi Aksara, 2011).

7 Mujiyem Sapti, "Kemampuan Koneksi Matematis (Tinjauan Terhadap Pendekatan Pembelajaran Savi)," LIMIT - Pendidikan Matematika 0, no. 11 (October 30, 2010), http://202.91.10.52/index.php/limit/article/view/26. 
dilakukan penelitian lanjutan dengan menerapkan model pembelajaran yang bisa meningkatkan kemampuan koneksi matematis ${ }^{8}$.

Berdasarkan permasalahan yang terjadi dilapangan dan berdasarkan saran dari penelitian sebelumnya, Maka peneliti tertarik untuk melakukan penelitian dengan merumuskan masalah penelitian yaitu apakah kemampuan koneksi matematika siswa yang mengikuti pembelajaran dengan pendekatan konstektual lebih baik daripada kemampuan koneksi matematika siswa dengan pendekatan konvensional di kelas VII SMP N 1 Banuhampu.

Tujuan penelitian ini adalah untuk mengetahui kemampuan koneksi matematika siswa yang mengikuti pembelajaran dengan pendekatan konstektual lebih baik daripada kemampuan koneksi matematika siswa dengan pendekatan konvensional di kelas VII SMP N 1 Banuhampu. Manfaat dari penelitian ini yaitu memberikan sumbangan pemikiran alternatif dalam upaya meningkatkan kualitas proses pembelajaran terutama mata pelajaran matematika di sekolah, bertambahnya wawasan tentang pendekatan pembelajaran konstektual dan terampil dalam membelajarkan siswa dengan pendekatan pembelajaran konstektual.

\section{Metode}

Jenis penelitian ini adalah penelitian eksperimen dengan rancangan penelitian The Static Group Comparison Design

Tabel 1. Rancangan Penelitian The Static Group Comparison Design

\begin{tabular}{ccc}
\hline Kelas & Treatment & Posttest \\
\hline Eksperimen & $X_{1}$ & $O$ \\
\hline Kontrol & $X_{2}$ & 0 \\
\hline
\end{tabular}

Keterangan:

$X_{1}=$ Perlakuan yang diberikan pada kelas eksperimen, yaitu kegiatan pembelajaran dengan menerapkan pendekatan pembelajaran konstektual

$X_{2}=$ Perlakuan yang diberikan pada kelas kontrol, yaitu kegiatan pembelajaran dengan menggunakan pembelajaran konvensional

$O=$ Tes akhir yang diberikan pada kelas eksperimen dan kelas kontrol di akhir penelitian.

Pada penelitian ini dilakukan penelitian pada kelas eksperimen dimana dikelas eksperimen diterapkan proses belajar mengajar dengan menerapkan

8 Rima Nur'afifah, "Kemampuan Koneksi Matematis Pada Bangun Ruang Sisi Lengkung" (Seminar Matematika Dan Pendidikan Matematika UNY, Yogyakarta, 2017), http://scholar.googleusercontent.com/scholar?q=cache:uRAwyb7vkCkJ:scholar.google.com /\&hl=en\&as_sdt $=0,5$. 
pendekatan pembelajaran konstektual dan kelas kontrol menerapkan proses belajar mengajar dengan menggunakan pembelajaran konvensional.

Populasi dalam penelitian ini adalah seluruh siswa kelas VII yang terdiri atas 5 lokal di SMPN 1 Banuhampu. Pengambilan sampel dilakukan secara cluster random sampling. Kelas sampel yang terpilih adalah kelas $V I I_{5}$ sebagai kelas eksperimen yang terdiri dari 30 orang dan kelas $V I I_{4}$ sebagai kelas kontrol yang terdiri dari 29 orang.

Instrumen yang digunakan dalam penelitian ini adalah tes kemampuan koneksi matematika siswa yang berupa soal essay yang diberikan di akhir penelitian. Tes tipe essay dipilih agar dapat melihat bagaimana kemampuan siswa sesungguhnya melalui uraian jawaban yang diberikan oleh siswa yang telah disusun sesuai dengan indikator kemampuan koneksi matematika yang di ukur. Analisis data yang digunakan dalam penelitian ini berupa Uji Normalitas, Uji Homogenitas Variansi serta Uji Hipotesis

\section{Pembahasan}

Deskripsi data penelitian yaitu data kemampuan koneksi matematika siswa yang diperoleh dari tes akhir yang diberikan. Peserta tes akhir adalah kelas $V I I_{5}$ sebagai kelas eksperimen yang terdiri dari 30 orang dan kelas $V I I_{4}$ sebagai kelas kontrol yang terdiri dari 29 orang.

Tes akhir yang diberikan terdiri atas empat buah soal berbentuk essay dengan alokasi waktu 80 menit. Setelah tes dilaksanakan, diperoleh data tentang kemampuan koneksi matematika siswa. hasil analisis tes kemampuan koneksi matematika siswa dapat dilihat pada tabel 2:

Tabel 2: Hasil Tes Kemampuan Koneksi Matematika Siswa

\begin{tabular}{lccccc}
\hline \multicolumn{1}{c}{ Kelas } & $\mathrm{N}$ & $X_{\text {maks }}$ & $X_{\min }$ & $\bar{x}$ & $S$ \\
\hline Eksperimen & 30 & 100 & 25 & 70,6 & 20,77 \\
Kontrol & 29 & 87,5 & 25 & 58,8 & 15,71 \\
\hline
\end{tabular}

Berdasarkan Tabel 2 terlihat bahwa terdapat perbedaan nilai rata-rata antara kelas eksperimen dan kelas kontrol, yaitu kelas eksperimen 70,6, sedangkan kelas kontrol mempunyai rata-rata 58,8. Jadi rata-rata pada kelas eksperimen lebih tinggi dari pada kelas kontrol. Berdasarkan data tersebut dapat dikatakan bahwa kemampuan koneksi matematika siswa yang mengikuti pembelajaran dengan pendekatan konstektual lebih baik daripada kemampuan koneksi matematika siswa yang mengikuti pembelajaran konvensional.

Untuk menarik kesimpulan tentang data hasil tes kemampuan koneksi matematika siswa pada kedua kelas sampel, dilakukan analisis secara 
statistik. Sebelum uji hipotesis, terlebih dahulu dilakukan uji normalitas dan uji homogenitas variansi terhadap hasil tes kedua kelas sampel.

Uji normalitas bertujuan untuk mengetahui apakah data sampel berdistribusi normal. Uji normalitas ini dilakukan dengan menggunakan Uji Liliefors. Diperoleh hasil seperti tabel 3.

Tabel 3. Hasil Uji Normalitas Tes Kemampuan Koneksi Matematika Kelas Sampel

\begin{tabular}{lcccccc}
\hline Kelas & $\alpha$ & $P_{\text {value }}$ & $\mathrm{N}$ & $L_{0}$ & $L_{\text {tabel }}$ & Distribusi \\
\hline Eksperimen & 0,05 & 0,119 & 30 & 0,11653 & 0,161 & Normal \\
Kontrol & 0,05 & 0,126 & 29 & 0,10824 & 0,161 & Normal \\
\hline
\end{tabular}

Berdasarkan Tabel 3, diperoleh $L_{0}<L_{\text {tabel }}$ baik pada kelas eksperimen maupun kelas kontrol. Begitu juga dengan harga $P$ yang diperoleh dengan menggunakan software minitab yaitu $P_{\text {value }}>\alpha$. Jadi, dapat disimpulkan bahwa kedua data sampel berdistribusi normal.

Perhitungan dengan uji homogenitas dapat dilihat pada tabel 4:

Tabel 4. Hasil Uji Homogenitas Kelas Sampel

\begin{tabular}{ccccl}
\hline$\alpha$ & $P_{\text {value }}$ & $X_{\text {tabel }}^{2}$ & $X_{\text {hitung }}^{2}$ & Kesimpulan \\
\hline 0,05 & 0,114 & 3,84 & 2,1812 & Variansi Homogen \\
\hline
\end{tabular}

Nilai $X_{\text {tabel }}^{2}>X_{\text {hitung }}^{2}$ pada taraf nyata $\alpha=0,05$, selain itu dengan software minitab diperoleh $P_{\text {value }}>\alpha$, sehingga terima $H_{0}$ artinya data samapel homogen.

Setelah dilakukan uji normalitas dan uji homogenitas variansi terhadap tes akhir, diketahui bahwa kedua kelas berdstribusi normal dan homogen. Selanjutnya dilakukan uji hipotesis dengan menggunakan uji-t pada taraf signifikan 0,05. Hasil uji-t pada kedua sampel dapat dilihat pada tabel 5.

Tabel 5. Hasil Uji Hipotesis Kemampuan Koneksi Matematika Kelas Sampel

\begin{tabular}{llrcc}
\hline Kelas & $\mathrm{N}$ & $\bar{x}$ & $t_{\text {hitung }}$ & $t_{\text {tabel }}$ \\
\hline Eksperimen & 30 & 70,6 & 2,45 & 1,67 \\
Kontrol & 29 & 58,8 & & \\
\hline
\end{tabular}

Berdasarkan Tabel 5 tersebut terlihat bahwa pada selang kepercayaan 95\% diperoleh $t_{\text {hitung }}>t_{\text {tabel }}$ dengan kriteria pengujia jika $t>t_{1-\alpha}$ Selanjutnya diperoleh bahwa $P_{\text {value }}=0,09$ lebih kecil dari $\alpha=0,05$. Berdasarkan hal tersebut dapat disimpulkan bahwa kemampuan koneksi matematika siswa yang mengikuti pembelajaran dengan pendekatan konstektual lebih baik daripada kemampuan koneksi matematika siswa yang 
menggunakan pendekatan konvensional pada siswa kelas VII di SMP N 1 Banuhampu.

Berdasarkan hasil deskripsi dan analisis data tes kemampuan koneksi matematika siswa terlihat bahwa kemampuan koneksi matematika siswa kelas eksperimen lebih tinggi daripada kemampuan koneksi matematika siswa kelas kontrol. Hal ini dapat dilihat dari nilai rata-rata siswa kelas eksperimen lebih tinggi dari nilai rata-rata siswa kelas kontrol. Nilai rata-rata siswa kelas eksperimen adalah 70,6 sedangkan nilai rata-rata kelas kontrol adalah 58,8.

Sejalan dengan itu, dapat juga dilihat dari hasil uji hipotesis yang menggunakan uji-t dan software minitab. Perhitungan memperoleh kemampuan koneksi matematika siswa yang mengikuti pembelajaran dengan pendekatan konstektual lebih baik daripada kemampuan koneksi matematika siswa yang mengikuti pembelajaran dengan pendekatan konvensional.

Berdasarkan deskripsi dan analisis data, diketahui bahwa kemampuan koneksi matematika siswa kelas eksperimen dengan siswa kelas kontrol memiliki perbedaan yang signifikan. Perbedaan tersebut disebabkan pada kelas eksperimen pembelajaran dengan pendekatan kontekstual guru mengaitkan antara materi yang diajarkannya dengan situasi dunia nyata siswa dan mendorong siswa membuat hubungan antara pengetahuan yang dimilikinya dengan penerapannya dalam kehidupan sehari-hari. Siswa dapat membangun sendiri koneksi matematikanya setelah selesai membaca, melakukan aktivitas belajar, menyelesaikan suatu masalah, dan membuat suatu keputusan.

Adapun dari tujuh komponen pembelajaran konstektual di dalam pengaplikasiannya, konstruktifisme merupakan komponen yang sangat penting dan sejalan dengan peningkatan kemampuan koneksi matematika. Pada konstruktivisme itu sendiri adalah proses membangun atau menyusun pengetahuan baru dalam struktur kognitif siswa berdasarkan pengalaman. Dengan demikian, di dalam proses pembelajaran siswa dituntut untuk berpikir mandiri dengan membangun pengetahuan yang baru melalui pengetahuan yang telah mereka dapatkan sebelumnya baik dari segi akademik maupun non akademik (kehidupan sehari-hari). Hal ini tentunya bermuara pada kemampuan siswa tersebut dalam menghubungkan (mengkoneksikan) antara apa yang akan mereka pelajari dengan topik-topik sebelumnya atau bahkan di luar matematika sehingga pada akhirnya siswa bisa menemukan (inkuiri) sendiri, konsep, prinsip, skill yang baru.

Untuk tes akhir kemampuan koneksi matematika siswa, soal yang diberikan memuat indikator-indikator kemampuan koneksi matematika. Indikator-indikator kemampuan koneksi -koneksi matematika yang tergambar pada soal yang diberikan adalah 
1) Mengenal hubungan antara ide-ide matematika

2) Memahami bagaimana ide-ide matematika saling berhubungan

3) Menggunakan hubungan antara ide-ide matematika.

Dengan proses dan tahap-tahap yang dilalui siswa, soal-soal tersebut dapat dijawab siswa dengan baik dan benar. Hal ini karena mereka sudah mampu menghubungkan soal yang diberikan dengan pemakaian rumus matematika yang tepat, jawabannya juga disertai dengan penjelasan pemakaian dari rumus yang digunakan.

Dibawah ini akan disajikan salah satu contoh jawaban siswa untuk soal tes kemampuan koneksi matematika yang sesuai dengan indikator koneksi. Berikut disajikan salah satu penyelesaian soal sesuai dengan koneksi matematika.

\section{Soal no 2.}

Pak Pronto yang berusia 87 tahun membuat surat wasiat untuk dua orang anaknya Bejo dan Siti. Dalam surat wasiatnya Pak Pronto menggambar sketsa sebidang tanah miliknya dalam bentuk persegi panjang sebagai berikut:

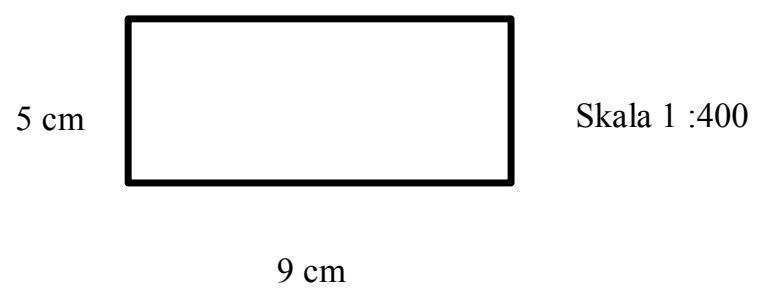

Sesuai dengan hukum waris yang berlaku ternyata tanah tersebut akan diwariskan untuk Bejo dan Siti dengan perbandingan 2:1

a. Tentukan ukuran sebenarnya tanah Pak Pronto

b. Tentukan luas tanah warisan Bejo

c. Tentukan luas tanah warisan Siti

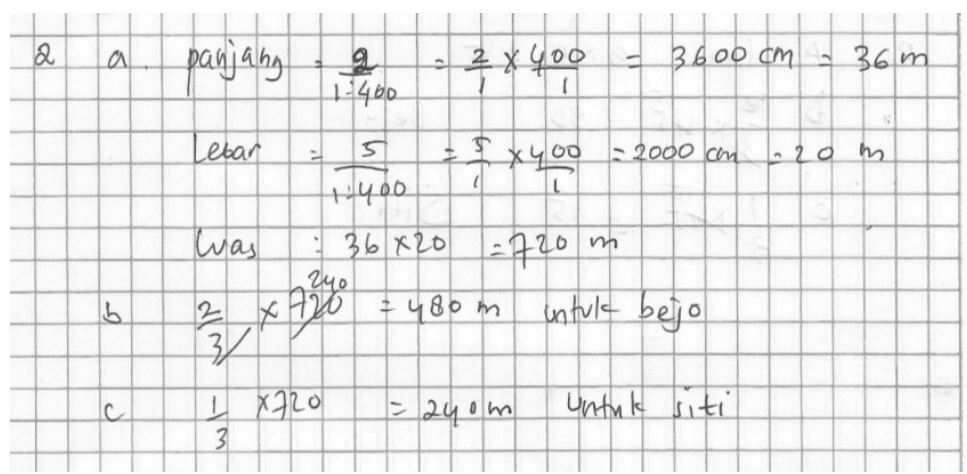

Gambar 1: Jawaban Siswa Tes Kemampuan Koneksi Matematika 


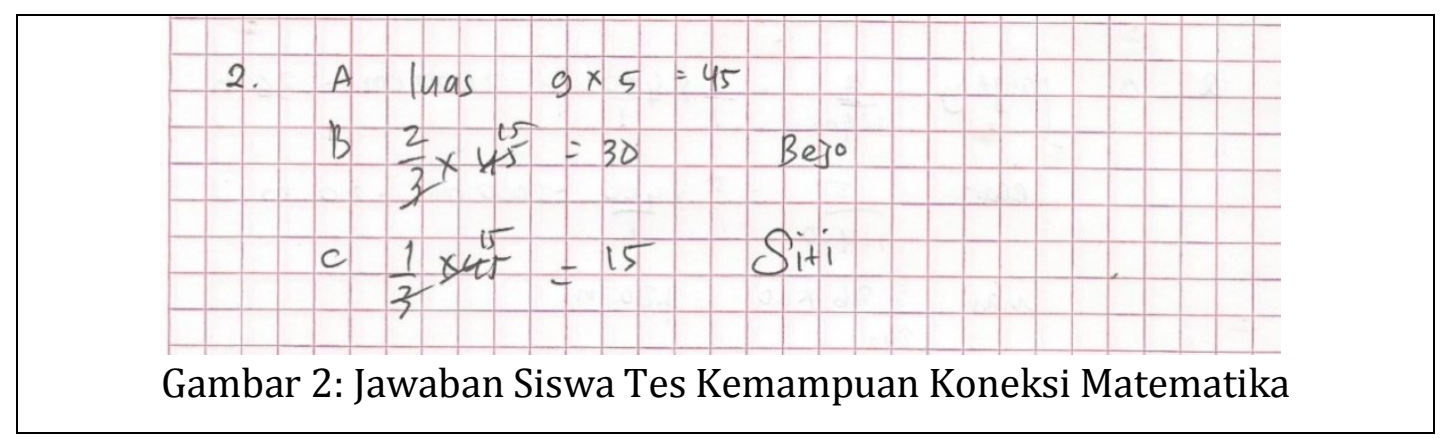

Pada Gambar 1 terlihat jawaban siswa sempurna dimana siswa sudah mampu mengenal hubungan antara ide-ide matematika, memahami bagaimana ide-ide matematika tersebut saling berhubungan, pada kasus di atas yaitu mencari ukuran sebenarnya tanah Pak Pronto, siswa harus tahu dulu berapa panjang dan lebar sebenarnya tanah tersebut, jawaban ini pun akan membantu untuk menjawab pertanyaan selanjutnya. Berdasarkan penilaian dengan rubrik penskoran tingkat kemampuan koneksi matematika "Jawaban benar, mengenal hubungan antar ide-ide matematika, memahami hubungan antara ide-ide matematik" siswa tersebut mendapatkan skor tertinggi yaitu 4. Pada gambar 2, bisa dilihat siswa menjawab soal tanpa memahami apa yang di minta soal, berdasarkan penilaian rubrik penskoran tingkat kemampuan koneksi matematika "Jawaban ada tetapi sama sekali tidak sesuai dengan kriteria” siswa tersebut mendapatkan skor 1

\section{Penutup}

\section{Simpulan}

Berdasarkan hasil analisis data diperoleh bahwa kemampuan koneksi matematika siswa mengikuti pembelajaran dengan pendekatan konstektual lebih baik daripada kemampuan koneksi matematika siswa dengan pendekatan konvensional di kelas VII SMPN 1 Banuhampu.

\section{Saran}

Sehubungan dengan hasil penelitian yang diperoleh, saran yang dapat diberikan adalah sebagai berikut:

1. Pendekatan pembelajaran konstektual memberikan dampak positif terhadap kemampuan koneksi matematika siswa, maka hendaknya guru matematika dapat menggunakan pendekatan pembelajaran kontekstual untuk meningkatkan kemampuan matematika siswa.

2. Untuk peneliti-peneliti yang lainnya, diharapkan ada penelitian lebih lanjut sebagai pengembangan dari penelitian ini dan agar menggunakan pendekatan konstektual pada pokok bahasan lain yang sesuai. 


\section{Daftar Pustaka}

Mathematics, Research Advisory Committee of the National Council of Teachers of. "NCTM Curriculum and Evaluation Standards for School Mathematics: Responses from the Research Community." Journal for Research in Mathematics Education 19, no. 4 (1988): 338-44. https://doi.org/10.2307/749544.

Muchlish, Masnur. KTSP Pembelajaran Berbasis Kompetensi Dan Konstektual. Malang: Bumi Aksara, 2011.

National Council of Teachers of Mathematics. Principles and Standards for School Mathematics. Reston, VA: National Council of Teachers of Mathematics, 2000. http://archive.org/details/principlesstanda00nati.

Nur'afifah, Rima. "Kemampuan Koneksi Matematis Pada Bangun Ruang Sisi Lengkung." "Yogyakarta, 2017. http://scholar.googleusercontent.com/scholar?q=cache:uRAwyb7vkCk $\mathrm{J}$ :scholar.google.com/\&hl=en\&as_sdt=0,5.

Sagala, Syaiful. Konsep Dan Makna Pembelajaran. Bandung: CV. Alfabeta, 2009.

Sapti, Mujiyem. "Kemampuan Koneksi Matematis (Tinjauan Terhadap Pendekatan Pembelajaran Savi)." LIMIT - Pendidikan Matematika 0, no. 11 (October 30, 2010). http://202.91.10.52/index.php/limit/article/view/26.

Suherman, Erman. Strategi Pembelajaran Matematika Kontemporer. Bandung: FMIPA UPI, n.d. 